\title{
MLH1 Gene Mutation
}

National Cancer Institute

\section{Source}

National Cancer Institute. MLH1 Gene Mutation. NCI Thesaurus. Code C118394.

A change in the nucleotide sequence of the MLH1 gene. 